\title{
Culture of bovine ovarian follicle wall sections maintained the highly estrogenic profile under basal and chemically defined conditions
}

\author{
R.B. Vasconcelos ${ }^{1}$, L.P. Salles ${ }^{2}$, I. Oliveira e Silva ${ }^{1}$, L.V.M. Gulart ${ }^{1}$, D.K. Souza ${ }^{1,3}$, F.A.G. Torres ${ }^{2}$, \\ A.L. Bocca ${ }^{4}$ and A.A.M. Rosa e Silva ${ }^{1}$ \\ ${ }^{1}$ Laboratório de Biotecnologia da Reprodução, Departamento de Ciências Fisiológicas, Instituto de Ciências Biológicas, \\ Universidade de Brasília, Brasília, DF, Brasil \\ ${ }^{2}$ Laboratório de Biologia Molecular, Departamento de Biologia Celular, Instituto de Ciências Biológicas, \\ Universidade de Brasília, Brasília, DF, Brasil \\ ${ }^{3}$ Faculdade de Ceilândia, Universidade de Brasília, Ceilândia, DF, Brasil \\ ${ }^{4}$ Departamento de Biologia Celular, Instituto de Ciências Biológicas, Universidade de Brasília, Brasília, DF, Brasil
}

\begin{abstract}
Follicle cultures reproduce in vitro the functional features observed in vivo. In a search for an ideal model, we cultured bovine antral follicle wall sections (FWS) in a serum-free defined medium (DM) known to induce 17 $\beta$-estradiol ( $E_{2}$ ) production, and in a nondefined medium (NDM) containing serum. Follicles were sectioned and cultured in NDM or DM for 24 or $48 \mathrm{~h}$. Morphological features were determined by light microscopy. Gene expression of steroidogenic enzymes and folliclestimulating hormone $(F S H)$ receptor were determined by RT-PCR; progesterone $\left(\mathrm{P}_{4}\right)$ and $\mathrm{E}_{2}$ concentrations in the media were measured by radioimmunoassay. DM, but not NDM, maintained an FWS morphology in vitro that was similar to fresh tissue. $\mathrm{DM}$ also induced an increase in the expression of all steroidogenic enzymes, except FSH receptor, but NDM did not. In both $\mathrm{DM}$ and NDM, there was a gradual increase in $\mathrm{P}_{4}$ throughout the culture period; however, $\mathrm{P}_{4}$ concentration was significantly higher in NDM. In both media, $E_{2}$ concentration was increased at $24 \mathrm{~h}$, followed by a decrease at $48 \mathrm{~h}$. The $E_{2}: P_{4}$ ratio was higher in DM than in NDM. These results suggest that DM maintains morphological structure, upregulates the expression of steroidogenic enzyme genes, and maintains steroid production with a high $\mathrm{E}_{2}: \mathrm{P}_{4}$ ratio in FWS cultures.
\end{abstract}

Key words: Ovary follicle wall section; FSH receptor; Gene expression; Steroidogenic enzymes; Hormone steroids; Morphological aspect

\section{Introduction}

Maintenance of $17 \beta$-estradiol $\left(E_{2}\right)$ production and increasing cholesterol side-chain cleavage A1 (CYP11A1) and aromatase (CYP19) expression are characteristics of healthy ovarian follicles growing in vivo $(1,2)$. One of the main goals of follicle culture is to reproduce in vitro the functional and biochemical features observed in vivo, including the expression of steroidogenic enzymes and the production of steroids (1-3) closely related to the fate of the follicle. In addition, follicle cell cultures allow study of the regulation of steroidogenesis and steroidogenic enzyme activity (4-7). This procedure contributes to understanding the physiology of steroidogenesis and, consequently, folliculogenesis.

One of the most relevant uses of follicle cell culture is to study factors that influence regulation of the steroidogenesis pathway and the fate of follicles both in vivo and in vitro. The upregulation of steroidogenic enzyme expression is related to follicular health and dominance $(1,2)$.

The luteinization process of isolated cultures of ovarian follicle cells, such as granulosa cells (GC), is characterized by increased progesterone $\left(P_{4}\right)$ and decreased $E_{2}$ in the presence of serum $(4,5)$. Gutierrez et al. (6) used a defined medium that allows steroid production and CYP19 activity in vitro. Under defined culture conditions, insulin-like growth factor 1 (IGF-1) and insulin stimulate bovine GC replication and steroid synthesis, and increase gene expression and the activity of CYP11A1 and CYP19 steroidogenic enzymes, independent of the presence of follicle-stimulating hormone ( $\mathrm{FSH}$ ) in the culture medium $(6,7)$, so both hormones tend to be prodominance factors.

Correspondence: A.A.M. Rosa e Silva, Departamento de Ciências Fisiológicas, Instituto de Ciências Biológicas, Universidade de Brasília, 70910-900 Brasília, DF, Brasil. Fax: +55-61-3107-2926. E-mail: aamresil@unb.br 
In the literature, there have been many reports of short-term cultures, most of which have used serum. The present report describes the development of a follicle wall section (FWS) culture system and the behavior of FWS in serum-free defined medium (DM) under basal and chemically defined conditions in the absence of FSH. Nondefined medium (NDM) is a commercial, luteinizing medium that includes serum $(4,5)$, and DM contains growth factors and antioxidants that positively affect cultured cells (6). Other DMs, as developed by Gutierrez et al. (6), allow bovine GC to respond, even in absence of $\mathrm{FSH}$, and produce high levels of steroids (8), characterizing an ideal model for the study of factors intervening in steroidogenesis, markers of follicle fate; and, consequently, the dominance, atresia, or luteinization processes in vitro. For these reasons, we studied the effect of a DM previously known to induce estrogen production in short-term culture of bovine follicle walls. We aimed to construct an in vitro model as similar as possible to the wall of the growing follicle for study of the cross-talk between the oocyte and surrounding granulosa cells as in a preovulatory follicle.

\section{Material and Methods}

\section{Preparation of bovine ovarian FWS}

Bovine ovaries (Bos taurus) at various stages of the estrous cycle were obtained from a slaughterhouse, transported to the laboratory in saline solution $(0.9 \%$ $\mathrm{NaCl}, \mathrm{w} / \mathrm{v}$, and $100 \mathrm{mg} / \mathrm{L}$ streptomycin), and maintained at $30-35^{\circ} \mathrm{C}$. Follicles were selected by size $(4-5 \mathrm{~mm})$, shape (spherical), fluid appearance (clear), and vascularization (well vascularized). Follicles $4-5 \mathrm{~mm}$ in diameter are thought to be at a stage capable of further development $(9,10)$.

Eighty-four follicles were isolated from different animals and dissected free of stroma in $37^{\circ} \mathrm{C}$ phosphate-buffered solution (PBS) under sterile conditions using surgical instruments $(11,12)$. FWS were derived from slices of intact bovine antral follicle wall sections and were composed of granulosa cells attached to the basement membrane and to some layers of mural theca cells. Isolated FWS weighed around $7 \mathrm{mg}$ and were maintained in $37^{\circ} \mathrm{C}$ PBS until transferred to culture medium (one FWS per well). Different FWS obtained from the same follicle were allocated to DM and NDM to compare the effects of culture in each medium.

\section{FWS culture media}

The media used for FWS culture were: 1) NDM: TCM199 with Earl's salts (Invitrogen-Gibco/BRL, USA), supplemented with $10 \%$ fetal calf serum, $11 \mathrm{mg} / \mathrm{mL}$ pyruvic acid, $200 \mathrm{ng} / \mathrm{mL} \mathrm{FSH}$ (Sigma-Aldrich, USA), $5 \mathrm{IU} / \mathrm{mL}$ penicillin and streptomycin as described by Channing (5); or 2) serum-free DM: minimum essential medium alpha (Invitrogen-Gibco/BRL), supplemented with polyvinyl alcohol (PVA; Sigma-Aldrich), bovine insulin (SigmaAldrich), human recombinant IGF-1 (Invitrogen Life Technologies, USA), androstenedione (Sigma-Aldrich), nonessential amino acids (Invitrogen-Gibco/BRL), human transferrin (Invitrogen-Gibco), sodium selenium (AcrosOrganics, USA), $10 \mathrm{mM}$ sodium bicarbonate (Invitrogen-Gibco/BRL), $0.02 \mathrm{M}$ HEPES, and 10,000 IU penicillin and streptomycin (Sigma-Aldrich), as described by Gutierrez et al. (6) and modified as described previously $(13,14)$ (Patent PI No. 0803140-1, deposit date December 5, 2008, applicant: Fundação Universidade de Brasília).

Both media were distributed on 96-well plates (Nunc) and pre-exposed to culture conditions $\left(38.5^{\circ} \mathrm{C}, 5 \%\right.$ $\mathrm{CO}_{2}: 95 \%$ air atmosphere with $95 \%$ humidity) for at least $2 \mathrm{~h}$ before FWS were added and cultured for 24 or $48 \mathrm{~h}$. The medium was not changed during the culture period.

\section{Morphological analysis}

Morphological analysis was performed using an optical microscope. For evaluation, follicles were divided into three groups ( $n=30 \mathrm{FWS}$ per group). One group was immediately processed (fresh tissue) and used as a control. The other two groups were incubated in either $100 \mu \mathrm{L}$ NDM or DM for 24 or $48 \mathrm{~h}$ as described above. After culture, the FWS in each group were washed with PBS and immediately processed.

The FWS in each group were fixed in $4 \%$ formalin overnight and embedded in paraffin. Samples were cut at 5-6 $\mu \mathrm{m}$ thickness from paraffin blocks with a rotary microtome (Leica Microsystems, Germany) and mounted on glass microscope slides (Superfrost Plus; Fisher, USA). Slices were stained with hematoxylin and eosin and analyzed by light microscopy using a Zeiss Axiophot microscope (Germany). Two slices from each FWS were prepared for microscopy, with three sequential cuts of each slice.

\section{Steroid assays}

Media were recovered from FWS ( $n=21$ FWS per group), following culture for 24 or $48 \mathrm{~h}$, and stored at $-20^{\circ} \mathrm{C}$ until steroid hormone analysis was performed. $\mathrm{P}_{4}$ and $E_{2}$ concentrations in the culture media were measured using radioimmunoassay kits (Coat-A-Count, Diagnostic Products, USA). The values obtained from radioimmunoassay were used to calculate the $E_{2}: P_{4}$ ratio for each FWS. The assay sensitivity for $P_{4}$ was $0.03 \mathrm{ng} / \mathrm{mL}$, and intra- and interassay coefficients of variation were 13.2 and $14.8 \%$, respectively. The assay sensitivity for $E_{2}$ was $10 \mathrm{pg} / \mathrm{mL}$ and intra- and interassay coefficients of variation were 7 and $8.1 \%$, respectively.

\section{Total RNA isolation and reverse transcription}

Selected follicles were sliced in three sections for the RT-PCR assays ( $n=72$ FWS per group). One part of each FWS was immediately processed (fresh tissue) 
while the other two parts were cultured in $100 \mu \mathrm{L}$ NDM or $\mathrm{DM}$, for 24 or $48 \mathrm{~h}$. Follicles were immediately processed after the pre-established culture periods. All experiments were performed in triplicate.

Fresh and cultured FWS (NDM or DM; 24 or 48 h) were homogenized in Trizol reagent and total RNA was extracted by the guanidium acid-isothyocyanate-phenol-chloroform method following the manufacturer's protocol (Invitrogen). RNA quality was assessed spectrophotometrically using the $A_{260} / A_{280}$ ratio (GeneQuant Pro UV/Vis spectrophotometer RNA/DNA calculator, Amersham Bioscience, USA). RNAs were reverse transcribed using the Superscript III First-Strand Synthesis System (Invitrogen). Briefly, $2 \mu \mathrm{g}$ total RNA was reverse transcribed with oligo(dT) in first-strand buffer $(3 \mathrm{mM} \mathrm{MgCl} 2,75 \mathrm{mM} \mathrm{KCl}$, $50 \mathrm{mM}$ Tris- $\mathrm{HCl}, \mathrm{pH}$ 8.3) containing $500 \mu \mathrm{M}$ deoxynucleotide triphosphates (dNTPs), $10 \mathrm{mM}$ dithiothreitol, $200 \mathrm{U}$ Superscript III RNase $\mathrm{H}$-free reverse transcriptase, and $200 \mathrm{ng}$ oligo(dT). Total reaction volume was $40 \mu \mathrm{L}$.

\section{Measurement of mRNA}

RT-PCR analyses for bovine steroidogenic acute regulatory protein (StAR), CYP11A1, cytochrome P450 17 alpha-hydroxylase (CYP17A1), 3 beta-hydroxysteroid dehydrogenase 1 (HSD3B1), CYP19, FSH receptor $(F S H R)$, and the housekeeping glyceraldehyde-3phosphate dehydrogenase (GAPDH) gene as an internal control were performed on the target cDNAs prepared from the fresh or cultured FWS using specific primers (Table 1). First, reaction mixes were prepared for each follicle template sample (first-strand reaction), containing all the PCR components except the specific primers, and distributed into $46 \mu \mathrm{L}$ aliquots for target gene amplification procedures.
All PCR reactions contained $2.5 \mathrm{mM} \mathrm{MgCl}_{2}, 2000 \mu \mathrm{M}$ dNTPs, $1.5 \cup$ Taq DNApol (GE Healthcare Life Sciences, USA), and $2 \mu \mathrm{L}$ cDNAs (first-strand reaction derived from the RT-PCR procedure), as templates in $50 \mathrm{mM}$ Tris- $\mathrm{HCl}$, $\mathrm{pH} 8.3$, reaction buffer. At the end, $2500 \mu \mathrm{M}$ of a forward and a reverse primer were added to the reaction mixture and placed in a thermal cycler. Target cDNAs were amplified following the hot-start PCR cycles as follows: $94^{\circ} \mathrm{C}$ for $2 \mathrm{~min}, 29$ cycles at $94^{\circ} \mathrm{C}$ for $30 \mathrm{~s}$, specific melting temperature (shown in Table 1) for $40 \mathrm{~s}$, and $72^{\circ} \mathrm{C}$ for $60 \mathrm{~s}$. The number of cycles was controlled to standardize analysis of the fold-increase in expression of each gene at the log phase.

Aliquots of PCR products $(10 \mu \mathrm{L})$ were electrophoresed on $2 \%$ agarose gels and visualized with ethidium bromide staining. The relative integrated density of each band was scanned and digitalized using a Typhoon ${ }^{\mathrm{TM}} 86$ Variable Mode Imager (Molecular Dynamics, Amersham Pharmacia Biotech, USA). The ratios of densitometric readings of the amplified target cDNAs and GAPDH were also calculated on GelEval 1.22 for Macintosh. The relative integrated density of all PCR products was scanned and digitalized using the Typhoon ${ }^{\mathrm{TM}} 86$ Variable Mode Imager.

\section{Statistical analysis}

Data obtained from NDM and DM groups were analyzed by two-way ANOVA followed by the Bonferroni least-significant difference test. Differences among NDM or DM data during the period of culture were tested for significance by one-way ANOVA also followed by the Bonferroni least-significant test. Differences between NDM and DM groups for each culture time were analyzed by the Student $t$-test. All data are reported

Table 1. Sequences of target bovine gene primers and melting temperatures.

\begin{tabular}{|c|c|c|c|}
\hline Gene & GenBank code & Primer & $\mathrm{Tm}$ \\
\hline \multirow[t]{2}{*}{ StAR } & NM_174189.2 & F: CTACAGACATGTGCGCAGCATG & $55^{\circ} \mathrm{C}$ \\
\hline & & R: CATGCGCTCCACAAGCTCTTC & \\
\hline \multirow[t]{2}{*}{ CYP11A1 } & NM_176644.2 & F: CAATGGCTGGCTTAACCTCTAC & $62^{\circ} \mathrm{C}$ \\
\hline & & R: TGGATTCAGCAGTGGGATGAAG & \\
\hline \multirow[t]{2}{*}{ CYP17A1 } & NM_174304.1 & F: TTCGTTTGGGTTCCAAGACGAC & $55^{\circ} \mathrm{C}$ \\
\hline & & R: GAAGTTGAAGCAGATAAAGCTG & \\
\hline \multirow[t]{2}{*}{ HSD3B1 } & NM_174343.2 & F: CAACGGCATCCTGACCAATCAC & $55^{\circ} \mathrm{C}$ \\
\hline & & R: CACGCTGTTGGAAGAAGTCAC & \\
\hline \multirow[t]{2}{*}{ CYP19 } & NM_174305.1 & F: GAGGACACATCCTCAATACCAG & $55^{\circ} \mathrm{C}$ \\
\hline & & R: CTTGGTGATGGAATCAGCACAG & \\
\hline \multirow[t]{2}{*}{ FSHR } & NM_174061.1 & F: GACCCTGATGCCTTCCAGAAC & $62^{\circ} \mathrm{C}$ \\
\hline & & R: CTTGGCCCGCAGCTTCTTAAG & \\
\hline \multirow[t]{2}{*}{ GAPDH } & NM_001034034.2 & F: CATTGACCTTCACTACATGGT & $55^{\circ} \mathrm{C}$ \\
\hline & & R: ACCCTTCAAGTGAGCCCCAG & \\
\hline
\end{tabular}

StAR: steroidogenic acute regulatory protein; CYP11A1: cholesterol side-chain cleavage A1; CYP17A1: cytochrome P450 17A1; HSD3B1: 3 beta-hydroxysteroid dehydrogenase 1; CYP19: aromatase; FSHR: follicle-stimulating hormone receptor; GAPDH: glyceraldehyde-3phosphate dehydrogenase (housekeeping gene). F: forward primer; R: reverse primer; Tm: specific melting temperature. 

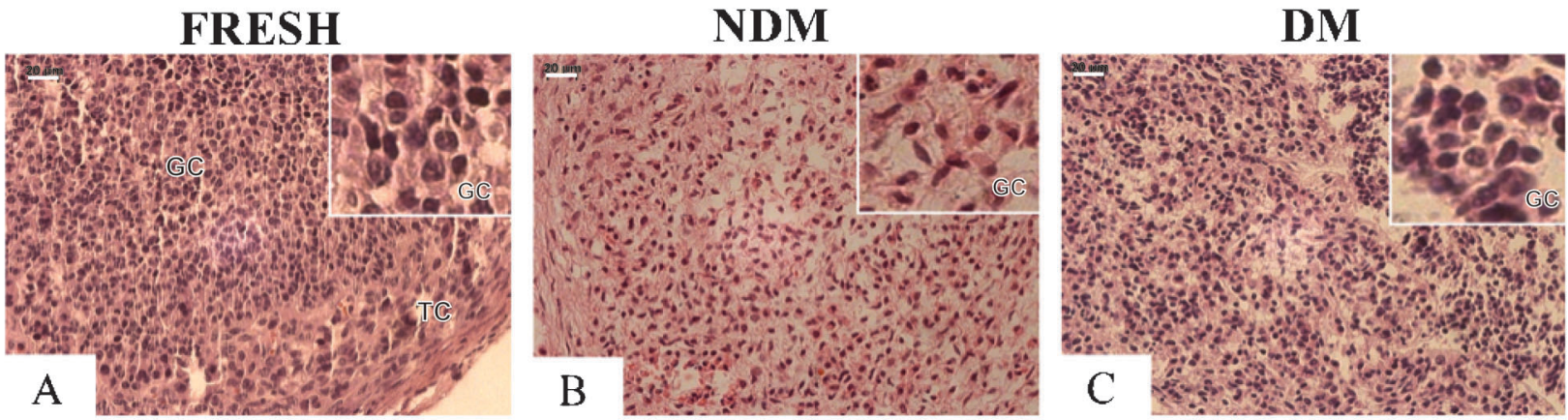

Figure 1. Morphological characteristics of granulosa cells (GC) and theca cells (TC) in $A$, fresh bovine ovarian follicle wall sections (FWS), FWS cultured in $B$, nondefined medium (NDM) or in $C$, defined medium (DM) after $48 \mathrm{~h}$ revealed by hematoxylin-eosin staining. Note the similar morphology between GC in Panels $A$ and $C$ and fibroblast-like GC in Panel $B$. The results of $24 \mathrm{~h}$ were similar to those observed at $48 \mathrm{~h}$ (data not shown). Bar $=20 \mu \mathrm{m}$.

as means $\pm S D$ and $\mathrm{P}<0.05$ was considered to be statistically significant.

\section{Results}

\section{FWS morphology}

Fresh FWS controls (Figure 1A) had round GC with a low cytoplasm-to-nucleus ratio, and similar results were observed in DM culture after $24 \mathrm{~h}$ (data not shown) and $48 \mathrm{~h}$ (Figure 1C). FWS cultured in NDM for 24 (data not shown) and $48 \mathrm{~h}$ (Figure $1 \mathrm{~B}$ ) revealed that cells lost their polyhedral shape and acquired an irregular and elongated fibroblast-like form.

\section{Steroid concentrations}

Concentration of $\mathrm{P}_{4}$ in the culture medium increased gradually from 24 to $48 \mathrm{~h}$ of culture in both experimental groups (DM and NDM; Table 2). However, $\mathrm{P}_{4}$ concentrations observed in the DM group were two times lower than the concentrations in the NDM group, in both culture periods $(\mathrm{P}<0.0001)$.

Concentrations of $E_{2}$ were higher after $24 \mathrm{~h}$ of incubation in both experimental groups, with higher concentrations in the NDM group than in the DM group. Lower, but stable, concentrations of $E_{2}$ were observed in both the NDM and DM groups cultured in FWS for $48 \mathrm{~h}$ (Table 2). There were no significant differences in $E_{2}$ concentration in the NDM and DM groups $(P=0.12$, two-way ANOVA).

The $E_{2}: P_{4}$ ratio was higher in DM than in NDM at each culture time (Figure 2); however, the ratio decreased in both groups during the culture period. There were no significant differences between the DM and NDM groups during the whole period of culture $(P=0.27$, two-way ANOVA).

\section{StAR, steroidogenic enzyme gene expression and FSHR}

Analyses of bovine StAR, steroidogenic enzymes (CYP11A1, CYP17A1, HSD3B1, and CYP19), and
FSHR mRNA expression were performed in fresh FWS and FWS cultured in NDM or DM for 24 or $48 \mathrm{~h}$. Gene expression was very low in fresh FWS; incubation in NDM did not alter expression of steroidogenic enzymes (Figure 3). Expression of all genes was enhanced in DM culture compared with fresh FWS or NDM culture (Figure 3).

However, culture in DM for 24 or $48 \mathrm{~h}$ was followed by increased expression of steroidogenic-related genes. Higher expressions of StAR (Figure 3A), CYP11A1 (Figure 3B), CYP17A1 (Figure 3C), and HSD3B1 (Figure 3D) were observed after 24 and $48 \mathrm{~h}$ of culture in DM compared with NDM. CYP19 (Figure 3E) showed augmented expression after $48 \mathrm{~h}$ of culture. Only FSHR (Figure 3F) was not significantly enhanced by DM culture. The banding pattern of steroidogenic enzymes and FSHR gene expression at $48 \mathrm{~h}$ is shown in Figure 4.

Table 2. Concentrations of progesterone and $17 \beta$-estradiol in media of cultured bovine FWS.

\begin{tabular}{lcc}
\hline & NDM & DM \\
\hline $\mathrm{P}_{4}\left(\mathrm{ng} \cdot \mathrm{mL}^{-1} \cdot 100 \mathrm{mg}^{-1}\right)$ & & \\
$\quad$ Fresh & $1.4 \pm 0.09$ & $1.5 \pm 0.13$ \\
$24 \mathrm{~h}$ & $180.8 \pm 43.2^{\mathrm{a}, \mathrm{A}}$ & $84.1 \pm 24.2^{\mathrm{b}, \mathrm{A}}$ \\
$\quad 48 \mathrm{~h}$ & $255.1 \pm 32.5^{\mathrm{a}, \mathrm{B}}$ & $101.1 \pm 19.2^{\mathrm{b}, \mathrm{B}}$ \\
$\mathrm{E}_{2}\left(\mathrm{pg} \cdot \mathrm{mL}^{-1} \cdot 100 \mathrm{mg}^{-1}\right)$ & & \\
$\quad$ Fresh & $12.4 \pm 2.46$ & $15.9 \pm 5.62$ \\
$24 \mathrm{~h}$ & $56.58 \pm 15.30^{\mathrm{a}, \mathrm{A}}$ & $41.52 \pm 19.84^{\mathrm{b}, \mathrm{A}}$ \\
$48 \mathrm{~h}$ & $31.74 \pm 12.39^{\mathrm{a}, \mathrm{B}}$ & $29.41 \pm 11.28^{\mathrm{a}, \mathrm{B}}$ \\
\hline
\end{tabular}

Steroid $\left[\mathrm{P}_{4}\right.$ (progesterone) and $\mathrm{E}_{2}$ (17 $\beta$-estradiol)] concentrations before (Fresh) and after follicle wall section (FWS) cultures in NDM (nondefined medium) or DM (defined medium) for 24 or $48 \mathrm{~h} .{ }^{\mathrm{a}, \mathrm{b}}$ Significant differences between NDM and DM ( $t$-test, $\mathrm{P}<0.05)$. ${ }^{\mathrm{A}, \mathrm{B}}$ Significant differences between data obtained at 24 and $48 \mathrm{~h}$ in NDM or DM (one-way ANOVA, $\mathrm{P}<0.05$ ). Two-way ANOVA indicated significant differences between groups for $\mathrm{P}_{4}$ $(P<0.0001)$, but not for $E_{2}$ concentration $(P=0.12)$. 


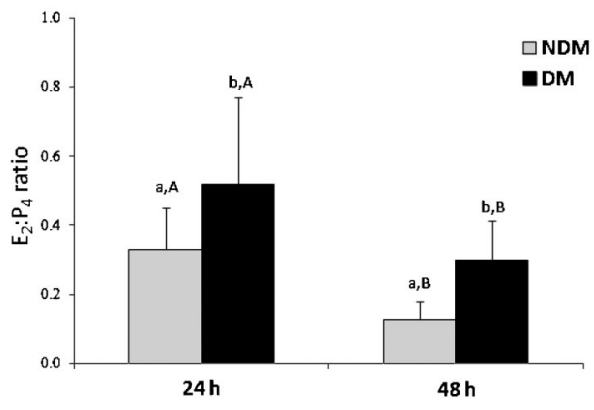

Figure 2. $E_{2}: P_{4}$ ratio of nondefined medium (NDM) and defined medium (DM) after 24 and $48 \mathrm{~h}$ of culture. ${ }^{\mathrm{a}, \mathrm{b}}$ Significant differences between NDM and DM ( $t$-test, $\mathrm{P}<0.05)$. $\mathrm{A}, \mathrm{B}$ Significant differences between data obtained at 24 and $48 \mathrm{~h}$ in NDM or DM (one-way ANOVA, $\mathrm{P}<0.05$ ). Two-way ANOVA indicated no significant differences between groups $(P=0.27)$.

\section{Discussion}

To our knowledge, this is the first study to describe the morphological, endocrine, and molecular events associated with culture of FWS in DM under basal and strictly
CYP CYP CYP HSD
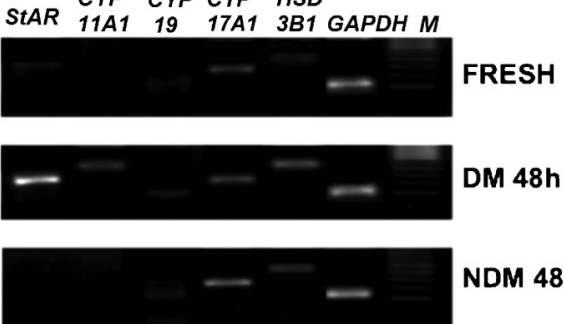

DM 48h

\section{NDM 48h}

Figure 4. Characterization of mRNA expression in fresh and cultured ovarian follicle wall sections after $48 \mathrm{~h}$ of culture in defined medium (DM) or nondefined medium (NDM). Genes: StAR, CYP11A1, CYP19, CYP17A1, HSD3B1, and the GAPDH housekeeping gene. $M$ : molecular marker.

chemically defined conditions (developed by our group) and NDM containing serum (5). The study also analyzed the steroid profile of cultured FWS, and established the fate of follicles in vitro. GC and theca cell (TC) co-culture of FWS for 24 and $48 \mathrm{~h}$ using a modified serum-free DM without FSH demonstrated, for the first time, the conditions under which FWS maintains the morphology of
A

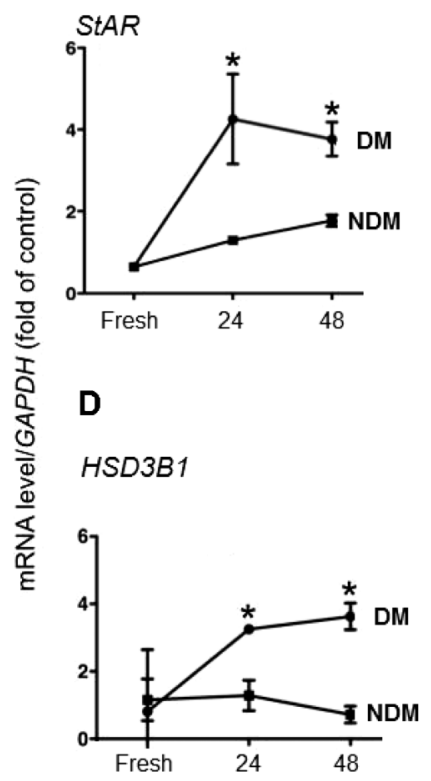

B

CYP11A1

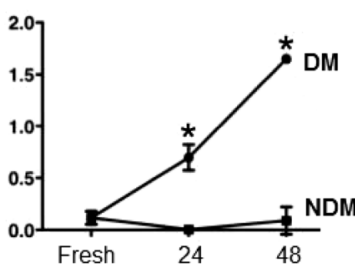

E

CYP19

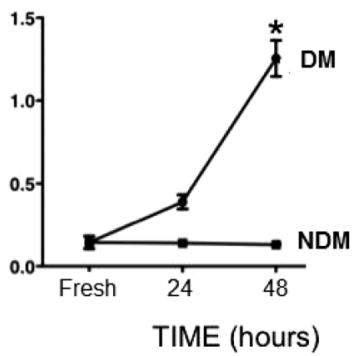

C

CYP17A1

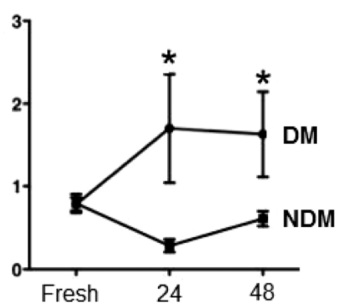

$\mathbf{F}$

FSHR

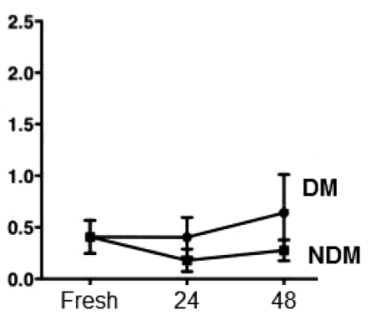

Figure 3. Semi-quantitative analysis of mRNA expression of steroidogenic acute regulatory protein (StAR), steroidogenic enzymes, and FSHR. Circles represent data for follicle wall sections (FWS) cultured in defined medium (DM) and squares represent data for FWS cultured in nondefined medium (NDM). A, Steroidogenic acute regulatory protein (StAR). $B$, Cholesterol side-chain cleavage A1 (CYP11A1). C, Cytochrome P450 17A1 (CYP17A1). D, 3 Beta-hydroxysteroid dehydrogenase 1 (HSD3B1). E, Aromatase (CYP19). F, Follicle-stimulating hormone receptor (FSHR). Data of fresh follicle mRNA were used as a control. Each transcript level of target genes was normalized on the basis of the glyceraldehyde-3-phosphate dehydrogenase (GAPDH) level. One-way ANOVA followed by the Bonferroni least-significant test were used to verify differences among NDM or DM data during the period of culture. Differences between NDM and DM groups for each time of culture were identified using the Student $t$-test. ${ }^{*} \mathrm{P}<0.05$, significantly different between culture periods and within group medium type. 
growing healthy follicles, upregulates steroidogenic enzymes, and sustains a high $\mathrm{E}_{2}: \mathrm{P}_{4}$ ratio.

In NDM culture, the morphology of FWS cells exhibited an elongated fibroblast-like appearance when compared with fresh FWS. The fibroblast phenotype may be related to culture conditions (15), the absence of the oocyte inside the follicle in vitro (16), the advance of the atresic process in vivo (17), or the absence of connections between GC and TC in monoculture and during luteinization $(5,18)$. Gutierrez et al. (6) also described the same fibroblast-like cells in the presence of high FSH concentrations. NDM also contains serum, which includes unknown concentrations of several molecules such as growth factors, steroids, cholesterol, and peptides that may affect the physiological processes of tissues $(19,20)$ and consequently cell morphology.

The concentration of $\mathrm{P}_{4}$ in NDM was at least twice as high as that observed in DM, and $E_{2}$ levels were increased after $24 \mathrm{~h}$ of culture and decreased after $48 \mathrm{~h}$. The increased levels of $\mathrm{P}_{4}$ may be related to the luteinization process observed in the presence of serum in the culture medium (5). In addition, the $E_{2}: P_{4}$ ratio was lower in NDM than in DM at 24 and $48 \mathrm{~h}$, demonstrating the luteinizing process in vitro. However, more experiments are needed to determine the fate of FWS cultured in NDM. NDM also did not alter gene expression of StAR, steroidogenic enzymes, and FSHR when compared to fresh FWS. The presence of serum decreased the expression of various genes in culture, as described previously (21) and as seen in our results.

A serum-free condition in vitro is crucial for understanding and control of the identity of all the constituents of serum that affect cultured cells $(8,22)$. Serum-free medium can be achieved by replacing serum with PVA, a synthetic polymer that does not have any negative effects on cells in cultures (23). In addition to PVA, DM is comprised of IGF-1, insulin, androstenedione, nonessential amino acids, selenium, and transferrin $(6,13,14)$. Insulin and IGF-1 can modulate the expression of steroidogenic enzymes, including CYP19, as well as steroidogenesis $(6,7)$, and insulin-transferrin-selenium can maintain GC viability in culture (24). Transferrin and selenium are essential trace elements that may have antioxidant activity in biological systems (24).

FWS cultured in DM maintained the round shape and high nucleus-to-cytoplasm relationship as seen in fresh FWS. The same result was reported by Gutierrez et al. (6) and Piccinato et al. (8), demonstrating the beneficial effects of our DM. $\mathrm{P}_{4}$ values in DM were at least one-half of those observed in NDM and, in addition, maintained a higher $E_{2}: P_{4}$ ratio, indicating that DM maintains steroidogenesis and avoids luteinization in vitro. In our results, the $\mathrm{P}_{4}$ increase was concomitant with increased expressions of CYP11A1, CYP17A1, and $H S D 3 B 1$, demonstrating a possible relationship between steroidogenesis and expression of these genes.
$\mathrm{E}_{2}$ concentration was stimulated after $24 \mathrm{~h}$ and decreased after $48 \mathrm{~h}$ of DM culture, and CYP19 expression was higher only at $48 \mathrm{~h}$. A possible explanation is that we can obtain higher levels of estrogens, maintained by higher levels of androstenedione supplementation in our DM, not only by CYP19 expression. In addition, our previous results (Vasconcelos RB, Oliveira e Silva I, Gulart LVM, Rosa e Silva AAM, unpublished data) demonstrated that changing $70 \%$ of the medium after $48 \mathrm{~h}$ of culture significantly enhanced the production of $\mathrm{E}_{2}$ in DM culture, reversing a possible inhibition of $E_{2}$ synthesis in the DM that was caused by the depletion of androstenedione in vitro. More experiments are needed to determine the $E_{2}$ profile during culture in DM.

DM also increased mRNA gene expression of enzymes related to steroidogenesis, with no $\mathrm{FSH}$ or luteinizing hormone (LH) present in the medium. The addition of insulin to GC culture medium induced CYP19 mRNA $(7,25)$; and after treatment with IGF-1, resulted in a significant increase in CYP11A1, HSD3B1, and CYP19 mRNA expression $(26,27)$ in the absence of $\mathrm{FSH}$ and $\mathrm{LH}$. In cultures of theca cells, the presence of inhibin produced by GC increased the expression of StAR, CYP17, and $H S D 3 B$, demonstrating the interaction of the two cell types in steroidogenesis (28).

Our results showed a positive effect of DM, resulting in increased levels of StAR, CYP11A1, CYP17A1, HSD3B1, and CYP19 mRNA expression. It is well known that insulin and IGF-1, as well as other regulators produced by follicular cells, regulate StAR, CYP11A1, and HSD3B expression of various species in culture (29). Previous reports of GC in culture did not show an increase in StAR expression (30); however, our results corroborate the data reported by Zhang et al. (31) that demonstrated upregulation of StAR gene expression in TC culture with insulin in vitro.

It is well known that $\mathrm{LH}$ controls CYP17A1 expression in theca cells (32); however, our results demonstrate that DM significantly enhanced CYP17A1 expression, independently of the presence of gonadotropins. It was demonstrated previously that insulin can influence CYP17 expression in cultures of porcine TC (31), as seen in our results.

The presence of theca cells in culture with GC (33) and IGF-1 (34) meant they were able to enhance CYP19 expression, and that no $\mathrm{FSH}$ was necessary to sustain $\mathrm{E}_{2}$ production and CYP19 activity in vitro $(6,8)$. In addition, CYP19 decreased significantly if no IGF-1 or insulin were included in the culture medium (7). These data demonstrate that, depending on the conditions of the defined culture medium, expression and activity of aromatase can be sustained independent of the gonadotropins, as seen in other papers and in our results. It should be noted that in DM culture at $48 \mathrm{~h}$, enzyme expression, including CYP19, had increased, and the $E_{2}: P_{4}$ ratio decreased significantly probably because $E_{2}$ inhibited synthesis and/or metabolism. 
While the steroidogenic enzymes were upregulated by DM, FSHR expression was not altered during $48 \mathrm{~h}$ of culture. Usually, FSHR expression is enhanced by FSH (34), and there is some evidence that IGF-1 enhances FSHR expression in vitro with no FSH in the medium (27). Our previous data (Vasconcelos RB, Oliveira e Silva I, Gulart LVM, Rosa e Silva AAM, unpublished data) demonstrated that FSHR mRNA expression was enhanced only after $72 \mathrm{~h}$ of culture, demonstrating the positive effect of DM.

In conclusion, our in vitro serum-free FWS-DM model was able to maintain cell morphology, steroid profile, and enhanced levels of steroidogenic enzyme mRNAs. Cell morphology observed in growing follicles was sustained by the presence of major ovarian steroids $\left(E_{2}\right.$ and $\left.P_{4}\right)$ and a high $E_{2}: P_{4}$ ratio. Increased expression of follicular dominance markers, (e.g., CYP19 and CYP11A1 mRNA expression), strongly indicates that FWS was similar to the follicular wall of the growing and dominant follicle. Based on the results obtained, this in vitro FWS-DM model could be used to study the effect of gonadotropins

\section{References}

1. Bao B, Garverick HA, Smith GW, Smith MF, Salfen BE, Youngquist RS. Changes in messenger ribonucleic acid encoding luteinizing hormone receptor, cytochrome P450-side chain cleavage, and aromatase are associated with recruitment and selection of bovine ovarian follicles. Biol Reprod 1997; 56: 1158-1168, doi: 10.1095/biolreprod56.5.1158.

2. Xu Z, Garverick HA, Smith GW, Smith MF, Hamilton SA, Youngquist RS. Expression of messenger ribonucleic acid encoding cytochrome P450 side-chain cleavage, cytochrome p450 17 alpha-hydroxylase, and cytochrome P450 aromatase in bovine follicles during the first follicular wave. Endocrinology 1995; 136: 981-989, doi: 10.1210/en.136.3.981.

3. Cheng Y, Inoue N, Matsuda-Minehata F, Goto Y, Maeda A, Manabe $\mathrm{N}$. Changes in expression and localization of connexin 43 mRNA and protein in porcine ovary granulosa cells during follicular atresia. J Reprod Dev 2005; 51: 627637, doi: 10.1262/jrd.17035.

4. Luck MR, Rodgers RJ, Findlay JK. Secretion and gene expression of inhibin, oxytocin and steroid hormones during the in vitro differentiation of bovine granulosa cells. Reprod Fertil Dev 1990; 2: 11-25, doi: 10.1071/RD9900011.

5. Channing CP. Effects of stage of the menstrual cycle and gonadotrophins on luteinization of rhesus monkey granulosa cells in culture. Endocrinology 1970; 87: 49-60, doi: 10.1210/endo-87-1-49.

6. Gutierrez CG, Campbell BK, Webb R. Development of a long-term bovine granulosa cell culture system: induction and maintenance of estradiol production, response to folliclestimulating hormone, and morphological characteristics. Biol Reprod 1997; 56: 608-616, doi: 10.1095/biolreprod56.3.608.

7. Silva JM, Price CA. Insulin and IGF-I are necessary for FSHinduced cytochrome P450 aromatase but not cytochrome P450 side-chain cleavage gene expression in oestrogenic bovine granulosa cells in vitro. J Endocrinol 2002; 174: independent of putative pro-dominant and pro-atretic factors, in follicular steroidogenesis and folliculogenesis. These results also allow construction of an in vitro model of a growing and/or dominant follicle, in which both follicular wall and oocyte may be present, to study the cross-talk between the germinal and somatic compartments involved in the in vitro regulation of oocyte maturation.

\section{Acknowledgments}

We thank Frigorífico Ponte Alta, Brasília, DF, Brazil, for supplying bovine ovaries, Izabel Cristina Rodrigues da Silva for helping with the statistical analysis, and the Molecular Biology Laboratory group for their support with the RT-PCR assay. We also thank Valter and Lair Gabriel for technical aid. Their help was possible through scientific initiation fellowships granted by CNPq. Research supported by FAP-DF, CNPq, FINATEC, and CAPES. R.B. Vasconcelos was the recipient of a CAPES fellowship of the Medical Sciences Program/University of Brasília.
499-507, doi: 10.1677/joe.0.1740499.

8. Piccinato CA, Montrezor LH, Collares CA, Vireque AA, Rosa e Silva AA. Norepinephrine stimulates progesterone production in highly estrogenic bovine granulosa cells cultured under serum-free, chemically defined conditions. Reprod Biol Endocrinol 2012; 10: 95, doi: 10.1186/1477-7827-10-95.

9. McNatty KP, Heath DA, Henderson KM, Lun S, Hurst PR, Ellis LM, et al. Some aspects of thecal and granulosa cell function during follicular development in the bovine ovary. J Reprod Fertil 1984; 72: 39-53, doi: 10.1530/jrf.0.0720039.

10. Ginther OJ, Wiltbank MC, Fricke PM, Gibbons JR, Kot K. Selection of the dominant follicle in cattle. Biol Reprod 1996; 55: 1187-1194, doi: 10.1095/biolreprod55.6.1187.

11. Komar CM, Berndtson AK, Evans AC, Fortune JE. Decline in circulating estradiol during the periovulatory period is correlated with decreases in estradiol and androgen, and in messenger RNA for p450 aromatase and p450 17alphahydroxylase, in bovine preovulatory follicles. Biol Reprod 2001; 64: 1797-1805, doi: 10.1095/biolreprod64.6.1797.

12. Richard FJ, Sirard MA. Effects of harvest methods of bovine oocytes co-cultured with follicular hemisections in vitro on nuclear maturation. Theriogenology 1996; 46: 1243-1250, doi: 10.1016/S0093-691X(96)00295-6.

13. Montrezor LH, Piccinato CA, Rosa e Silva AAM. Polyvinyl alcohol is effective in a defined medium long-term bovine granulosa cell culture in the maintenance of $17 \beta$-estradiol production. Biol Reprod 2002; 66 (Suppl 1): 211 (Abstract), doi: $10.1095 /$ biolreprod66.1.211

14. Piccinato CA, Montrezor LH, Rosa e Silva AAM. Norepinephrine stimulates steroidogenesis in bovine granulosa cells cultured under chemically defined conditions (PVA). Biol Reprod 2002; 66 (Suppl 1): 210 (Abstract).

15. Allegrucci $C$, Hunter MG, Webb R, Luck MR. Interaction of bovine granulosa and theca cells in a novel serum-free 
co-culture system. Reproduction 2003; 126: 527-538, doi: 10.1530/rep.0.1260527.

16. Nekola MV, Nalbandov AV. Morphological changes of rat follicular cells as influenced by oocytes. Biol Reprod 1971; 4: $154-160$

17. Pedersen HG, Watson ED, Telfer EE. Analysis of atresia in equine follicles using histology, fresh granulosa cell morphology and detection of DNA fragmentation. Reproduction 2003; 125: 417-423, doi: 10.1530/rep.0.1250417.

18. Tajima K, Orisaka M, Yata H, Goto K, Hosokawa K, Kotsuji $F$. Role of granulosa and theca cell interactions in ovarian follicular maturation. Microsc Res Tech 2006; 69: 450-458, doi: 10.1002/jemt.20304.

19. Gardner DK. Mammalian embryo culture in the absence of serum or somatic cell support. Cell Biol Int 1994; 18: 11631179, doi: 10.1006/cbir.1994.1043.

20. Mingoti GZ, Garcia JM, Rosa-e-Silva AA. Steroidogenesis in cumulus cells of bovine cumulus-oocyte-complexes matured in vitro with BSA and different concentrations of steroids. Anim Reprod Sci 2002; 69: 175-186, doi: 10.1016/ S0378-4320(01)00187-7.

21. Calder MD, Caveney AN, Sirard MA, Watson AJ. Effect of serum and cumulus cell expansion on marker gene transcripts in bovine cumulus-oocyte complexes during maturation in vitro. Fertil Steril 2005; 83 (Suppl 1): 10771085, doi: 10.1016/j.fertnstert.2004.12.012.

22. Faes MR, Caldas-Bussiere MC, Viana KS, Dias BL, Costa $\mathrm{FR}$, Escocard RM. Nitric oxide regulates steroid synthesis by bovine antral granulosa cells in a chemically defined medium. Anim Reprod Sci 2009; 110: 222-236, doi: 10.1016/j.anireprosci.2008.01.018.

23. Vireque AA, Camargo LS, Serapiao RV, Rosa e Silva AA, Watanabe YF, Ferreira EM, et al. Preimplantation development and expression of Hsp-70 and Bax genes in bovine blastocysts derived from oocytes matured in alpha-MEM supplemented with growth factors and synthetic macromolecules. Theriogenology 2009; 71: 620-627, doi: 10.1016/j.theriogenology.2008.09.028.

24. Quirk SM, Harman RM, Cowan RG. Regulation of Fas antigen (Fas, CD95)-mediated apoptosis of bovine granulosa cells by serum and growth factors. Biol Reprod 2000; 63: 1278-1284, doi: 10.1095/biolreprod63.5.1278.

25. Silva JM, Price CA. Effect of follicle-stimulating hormone on steroid secretion and messenger ribonucleic acids encoding cytochromes P450 aromatase and cholesterol side-chain cleavage in bovine granulosa cells in vitro. Biol Reprod 2000; 62: 186-191, doi: 10.1095/biolreprod62.1.186.

26. Magoffin DA, Weitsman SR. Insulin-like growth factor-I stimulates the expression of 3 beta-hydroxysteroid dehydrogenase messenger ribonucleic acid in ovarian theca-interstitial cells. Biol Reprod 1993; 48: 1166-1173, doi: 10.1095/biolreprod48.5.1166.

27. Mani AM, Fenwick MA, Cheng Z, Sharma MK, Singh D, Wathes DC. IGF1 induces up-regulation of steroidogenic and apoptotic regulatory genes via activation of phosphatidylinositol-dependent kinase/AKT in bovine granulosa cells. Reproduction 2010; 139: 139-151, doi: 10.1530/ REP-09-0050.

28. Young JM, McNeilly AS. Inhibin removes the inhibitory effects of activin on steroid enzyme expression and androgen production by normal ovarian thecal cells. $\mathrm{J} \mathrm{Mol}$ Endocrinol 2012; 48: 49-60, doi: 10.1530/JME-11-0134.

29. Lavoie HA, King SR. Transcriptional regulation of steroidogenic genes: STARD1, CYP11A1 and HSD3B. Exp Biol Med 2009; 234: 880-907, doi: 10.3181/0903-MR-97.

30. Sahmi M, Nicola ES, Silva JM, Price CA. Expression of 17beta- and 3beta-hydroxysteroid dehydrogenases and steroidogenic acute regulatory protein in non-luteinizing bovine granulosa cells in vitro. Mol Cell Endocrinol 2004; 223: 43-54, doi: 10.1016/j.mce.2004.05.010.

31. Zhang G, Garmey JC, Veldhuis JD. Interactive stimulation by luteinizing hormone and insulin of the steroidogenic acute regulatory (StAR) protein and 17alpha-hydroxylase/17,20lyase (CYP17) genes in porcine theca cells. Endocrinology 2000; 141: 2735-2742, doi: 10.1210/en.141.8.2735.

32. Murayama $\mathrm{C}$, Miyazaki $\mathrm{H}$, Miyamoto A, Shimizu T. Luteinizing hormone $(\mathrm{LH})$ regulates production of androstenedione and progesterone via control of histone acetylation of StAR and CYP17 promoters in ovarian theca cells. Mol Cell Endocrinol 2012; 350: 1-9, doi: 10.1016/j.mce.2011.11.014.

33. Orisaka M, Mizutani T, Tajima K, Orisaka S, Shukunami K, Miyamoto $\mathrm{K}$, et al. Effects of ovarian theca cells on granulosa cell differentiation during gonadotropin-independent follicular growth in cattle. Mol Reprod Dev 2006; 73: 737-744, doi: 10.1002/mrd.20246.

34. Glister C, Satchell L, Knight PG. Granulosal and thecal expression of bone morphogenetic protein- and activin-binding protein mRNA transcripts during bovine follicle development and factors modulating their expression in vitro. Reproduction 2011; 142: 581-591, doi: 10.1530/REP-11-0150. 